\title{
Matters of scale and the politics of the Food Safety Modernization Act
}

\author{
Neva Hassanein
}

Accepted: 29 September 2011/Published online: 18 October 2011

(C) Springer Science+Business Media B.V. 2011

\begin{abstract}
Signed into law in early 2011, the Food Safety Modernization Act (FSMA) marked the first major overhaul of the United States' regulatory system for food safety since the 1930s. This presidential address explores how the social movement for local and regional food systems influenced the debates around the FSMA and, in particular, how issues of scale became pivotal in those debates. Specifically, a key question revolved around whether or not the proposed regulations should apply to small farms and processors who sell directly to consumers in local markets. Advocates of the so-called "Tester amendment" aimed to create a scale-sensitive alternative to the requirements in the bill. This address lays out the three interrelated arguments that amendment advocates used. The first was the idea that food safety risks are different at different scales, and therefore the rules should reflect those differences. Their second argument revolved around the character of the local, direct markets of small producers and the social relationships embedded within them. The third argument used to support the Tester amendment is that the costs of complying with the detailed regulatory requirements of the new food safety law place a disproportionately large burden on small producers and that might thwart the emerging market for local food as an alternative to industrial agriculture. I conclude by suggesting some research and policy
\end{abstract}

Paper presented at the 2011 annual meeting of the Agriculture, Food and Human Values Society, held at the University of Montana, Missoula, in June 2011. It is dedicated to the memory of Jeanne Charter - an innovative rancher, tireless activist, and dear friend. This paper was not subjected to the journal's standard peer review process.

N. Hassanein $(\bowtie)$

Environmental Studies Program, University of Montana,

Rankin Hall, Missoula, MT 59812, USA

e-mail: neva.hassanein@umontana.edu questions that could be explored more fully, both with respect to this case and with respect to alternative agri-food movements more generally.

Keywords Local food movement · Food safety · Food Safety Modernization Act

\section{Introduction}

In a rare display of bi-partisan support, the 111th Congress of the United States passed the Food Safety Modernization Act in December 2010. And then, just after the New Year, President Barack Obama signed the bill into law. The legislation was the first major overhaul of the US regulatory system for food safety since the 1930s. For those of us interested in the politics of food and agriculture, there are a variety of lenses through which we might want to look at issues of food safety and at the passage and implementation of this major new law.

The lens of interest to me- and the focus of my remarks today-is how the social movement for local and regional food systems influenced the debates around the Food Safety Modernization Act (FSMA) and, in particular, how issues of scale became pivotal in those debates. My aim is to use this story to raise some research and policy questions that could be explored more fully, both with respect to this case and with respect to alternative agri-food movements more generally.

\section{Passage of the FSMA}

First, let me give you a brief overview of the major provisions of the Act, which grants significant new authority to 
the Food and Drug Administration (FDA 2011). The FDA is the agency that oversees $80 \%$ of the nation's food. ${ }^{1}$ The broad purpose of the Act is to give the FDA the ability to require "risk-based," preventative controls across the food supply, rather than to respond only after people have become ill from foodborne pathogens.

Under FSMA, food manufacturers must examine their processing systems to identify ways that food products might become contaminated, and then they have to develop plans to try to keep contamination from happening. ${ }^{2}$ Manufacturers will share those plans with the FDA and provide records regarding how they are carrying the plans out. The Act also requires the agency to inspect facilities more frequently, especially for so-called "high-risk" foods. In the event of an outbreak of foodborne illnesses, the FDA now has the authority to order a recall of contaminated food. In the past, recalls were only voluntary, meaning that contaminated food could be consumed even after a threat was identified. Lastly, for the first time ever, foods produced overseas and imported into the US will be subject to a foreign-supplier verification program and thus have to meet the same standards as foods produced here. So, that's the 236-page law in a nutshell.

That the bill passed and that it garnered bi-partisan support is actually fairly remarkable. Congress had debated and failed to pass similar reforms for many years (Delind and Howard 2008). But a series of highly-publicized food safety scandals seem to have finally compelled action. For example, just in the last 5 years, there have been major recalls in the US of spinach, beef, peanuts, instant milk, Romaine lettuce, pistachios, cookie dough, and more. As a result of these and other tainted foods, the Centers for Disease Control and Prevention now estimates that each year, 1 in 6 Americans get sick; 128,000 are hospitalized; and 3,000 die from foodborne diseases (FDA 2011). At the time of our conference in June 2010, it was not at all clear that the latest version of the food safety bill really had a chance. The bill had passed the House of Representatives, but it was stuck in the Senate.

Then, in August 2010, the egg story broke. Two huge egg operations in Iowa caused a major salmonella outbreak, with some 1,500 reported illnesses and probably thousands more that went unreported. In the largest incident of this type, Wright County Eggs and Hillandale Egg Farm eventually recalled 550 million eggs that had been sold under many different brand names in 22 states (FDA 2010). Much of the public discourse around this outbreak

\footnotetext{
1 The FDA regulates all foods except meat, poultry, and processed eggs, which are regulated by the US Department of Agriculture.

2 These plans are typically referred to as Hazard Analysis and Critical Control Point (HACCP). See Nestle (2010) for discussion of this method of trying to keep pathogens out of the food supply.
}

revolved around the government's failure to protect public health due to flaws in the regulatory process, including the fact that the FDA had no inspection history for these huge operations that produce billions of eggs a year. Leading national consumer groups-organized into the Make Our Food Safe Coalition ${ }^{3}$ - clearly linked the egg crisis to the need to revamp food safety regulations and to move the food safety bill that had been languishing in the Senate (Martin 2010).

\section{Matters of scale}

The solution that was proposed-and that was largely agreed upon by the consumer groups and by the highlyinfluential associations representing the food industrywas to establish a uniform set of standards that would employ a so-called "scientific, risk-based approach" to regulation and to preventing microbial contaminated food from entering the market. Such an approach, they argued, should apply to all food producers regardless of their scale of production and regardless of their geographic scope of distribution (Bottemiller 2010). As our colleagues DeLind and Howard (2008) argued in an excellent article a few years ago, advocacy for this kind of standardized approach to food safety regulation that would apply regardless of the scale has been the typical approach historically.

Yet, in the case of the Food Safety Modernization Act, scale did come into play and became one of the major sticking points that had to be addressed before the bill could move out of the Senate. A key question in the policy debates last fall revolved around whether or not the proposed regulations should apply to small farms and processors who sell directly to consumers in local markets. Specifically, a coalition of 128 national, state, and local organizations and food cooperatives pushed for an amendment sponsored by Senator Jon Tester of Montana and Senator Kay Hagan of North Carolina. ${ }^{4}$

The so-called "Tester amendment" aimed to create a scale-sensitive alternative to the requirements in the bill for "preventative control plans" (sometimes known as the HACCP provision). This alternative was achieved by providing a multi-pronged test to exempt qualified small processing businesses and small farms that sell directly to consumers, restaurants, or grocery stores within a limited geographic range. In the version of the amendment that ultimately passed, small scale will be determined based on

\footnotetext{
${ }^{3}$ See http://www.makeourfoodsafe.org for a list of coalition members.

4 Two organizations - the Farm and Ranch Freedom Alliance and the Western Organization of Resource Councils-led the coalitionbuilding effort.
} 
whether those facilities or farms that sell the majority of their food products directly to the end user generate less than $\$ 500,000$ in sales annually (based on a three-year average of sales). The geographic scope of distribution will be based on whether those direct sales are within the same state or are within 275 miles of the facility or farm. While these qualified entities would be exempt from the control plans required in the new law, they would still be required to meet all applicable state and local food safety regulations. In addition, any farm or facility that opts for compliance based on the above criteria would have to prominently display their name and address on the label or at point of purchase. ${ }^{5}$

Supporters of the Tester amendment framed their opposition to a "one-size-fits-all" approach to food safety regulations around three interrelated arguments. ${ }^{6}$ The first argument had to do with the idea that food safety risks are different at different scales, and therefore the rules should reflect those differences. Supporters of the Tester amendment argued that the risks of spreading pathogens in large industrial food production and processing systems are much greater than those associated with small farms and processors producing and selling into local markets. As Grist's senior food writer, Tom Philpott, put it, "If I cram tens of thousands of hens together in cages to produce eggs, I'm creating egg-cellent conditions for pathogens that endanger millions of people across the nation with a single week's output. If I produce eggs with an outdoor flock to sell at a farmers market, I create dramatically less hazardous conditions and risk endangering mere dozens of people" (Grist 2010). In other words, the conditions in large-scale industrial systems often favor the emergence and spread of pathogens, making them more hazardous, and threatening many more people than shorter supply chains do.

By contrast, consumer and industry groups tended to emphasize the idea that certain foods pose higher risks irrespective of scale, and therefore regulations ought to prioritize those foods, for instance when determining the frequency of inspections. The notion that certain crops, like leafy greens, pose greater risks is based on the fact that we tend to eat them raw and that the surface of some fruits and vegetables is more likely to harbor bacteria than other crops. In response, Ferd Hoefner, of the National Sustainable Agriculture Coalition, expressed fundamental disagreement over the idea of high-risk foods. Hoefner argued

\footnotetext{
${ }^{5}$ For the exact language and a summary of the Tester Amendment, see http://tester.senate.gov/Legislation/index.cfm.

${ }^{6}$ The arguments presented here are based on a review of news stories; letters and publications by trade and advocacy organizations; and Grist Magazine's online (http://www.grist.org/) series called "Food Fight," which included lengthy discussion in a virtual roundtable on scale issues around the FSMA.
}

that "Particular practices, irrigation methods, processing techniques, packaging types, and distribution methods can be more or less risky, but the food or commodity, in and of itself as a category, is not where the risk lies" (NSAC 2010).

The disagreement over where the "real risk" of spreading pathogens lies is one of the reasons that the consumer groups long opposed passage of the Tester amendment. They were concerned that exemptions for small scale agriculture and local food systems might threaten public health. Yet, the Make Our Food Safe Coalition did eventually compromise, and helped refine the scope of the final amendment in mid-November, when they realized the bill likely would not have survived that session of Congress otherwise.

Organizations representing agribusinesses, however, opposed the Tester amendment especially vehemently, and completely rejected the idea that scale matters when assessing risk. For example, the Western Growers Association-whose members grow, pack, and ship about half of the nation's supply of fresh produce-repeatedly made statements like the following: "Microbial contamination knows no boundaries. It can affect the smallest farm or garden plots as well as a larger operation. It can come from your backyard or travel long distances. It can be present in an organic or conventional crop. It may be present in raw or processed food. Any time it occurs, someone, somewhere may be at risk" (WGA 2010). The WGA's position was diametrically opposed to that put forward by Tester amendment advocates, that is, the idea that the potential risk of spreading pathogens is inherently limited in smallscale food production and distribution.

The second argument from amendment proponents revolved around the character of those local, direct markets of small producers and the social relationships embedded within them. In a letter signed by 128 organizations and sent to all US Senators, proponents of the Tester amendment argued that community-based food systems foster food safety by "providing the opportunity for consumers to know their farmers, to choose products on the basis of that relationship, and to readily trace any problems if they occur." ${ }^{7}$ In other words, supporters argued that these direct social relationships allow the consumer to hold the local food producer accountable, and that if problems do occur, the source can be traced more easily than is possible in national and international food supply chains.

On the flip side of the relationship, it was argued that farmers selling directly are likely to feel a sense of responsibility towards their customers, and they will take great care in the safety of their product, knowing that the

\footnotetext{
7 The coalition letter supporting the final agreement on the amendment is available at http://tester.senate.gov/Legislation/index.cfm.
} 
relationship and their livelihood will be jeopardized if they make people sick. As Senator Tester explained in his floor speech on the issue, farmers selling directly and locally have "pride of ownership there that is real...They raise food. They don't raise a commodity, as when operations get bigger and bigger. There is a direct customer relationship...that means a lot."

The third argument used to support the Tester amendment was that the costs of complying with the detailed regulatory requirements of the new food safety law place a disproportionately large burden on small producers. In conjunction with the first two arguments I just described, which both claim that food safety risks are reduced for smaller scale producers, this disproportionate regulatory cost burden was claimed to be unwarranted and unfair, especially because small producers would continue to be regulated under existing state and local laws. That is, if the risk of an outbreak affecting large numbers of people is much less in a local food system, and if the social relationships foster both producer responsibility and accountability, then the detailed regulatory requirements of the new food safety law are both unnecessary to ensure public safety and unduly burdensome on small farmers and processors selling in direct, local markets.

The argument about the costs of compliance associated with the food safety bill was more than a simple desire to avoid those costs. Proponents of the Tester amendment argued that if the costs of compliance drove small producers out of business, it would ultimately encourage more consolidation and concentration of economic power in the food industry, and, therefore, reduce consumer choice. As one amendment proponent put it, "Large industrial operations that threaten public health as a matter of course must be regulated robustly, but not in a way that wipes out smaller players and consolidates the food industry still more. Today, thousands of small farms and food purveyors are building out alternative food systems rooted in community development and ecological sustainability, not just profit. I can testify firsthand that they are economically fragile... Without the Tester amendment, S. 510 could end up only slightly reigning in the ruinous practices of large players while clobbering these alternative food networks" (Grist 2010).

\section{Take home message}

In my comments today, I have only been able to touch on some of the arguments hotly debated in the media and among the various policy makers and lobbyists involved in the negotiations around the bill. But, in the course of the discussions, one thing became very clear. That is, there is not a lot of definitive evidence to support or refute the arguments related to scale. As a result, one of the provisions that got included in the Tester amendment was a requirement that the FDA conduct a study that will, for the first time, look at issues of scale and risk in relation to foodborne illnesses. So, my first take-home message for you today is that I hope that some of us will get involved in that study process and use our expertise to really explore the intersection of scale and food safety risks and to inform the implementation of this new law (which by the way is not at all assured because of the current budget situation at the federal level).

A second area of inquiry that I hope agri-food scholars will take on is to systematically analyze existing policies and regulations to determine whether and to what extent they favor one scale of production and distribution over another. What policy changes, if any, might be necessary for addressing those disparities? What could it mean in practice to have scale-sensitive policies? These are questions that DeLind and Howard (2008) began to explore in their article I mentioned earlier. That piece, published in our own journal, Agriculture and Human Values, is an example of the important role that scholars can play in public policy. As one of the activists who led the effort to pass the Tester amendment told me, Laura and Phil's article "inspired" them to really push for the amendment. Let's see how we can take that a step further.

Although the list could go on and I welcome dialogue about what the case of the FSMA means, the final thought that I would like to put out there is this. As someone interested in social movements, I think one of the most interesting aspects of the FSMA and the Tester amendment case is that it suggests that the local food movement has gained greater power in the federal policy arena. Now, to be sure, this is not the first foray of movement actors into federal policy - there have been important successes in the past, such as funding for the Community Food Projects Grant Program and for farm-to-school programs passed as part of the Child Nutrition Reauthorization Act last year. It seems to me that the FSMA story is a bit different because the law is largely regulatory, while other federal policy successes have primarily been about securing federal resources towards issues that concern movement actors.

Why is this significant? As a group largely dedicated to public scholarship, I hope we will seek to understand the local food movement as a dynamic, evolving, and contentious process. Movements move. They are not static "things." Nor do all movement actors agree on goals or strategies. As a result, the local food movement-and alternative agri-food movements more generally-present interesting challenges to those of us who try to analyze its characteristics and dynamics. For instance, some advocates of local food were not satisfied with the Tester amendment. As a result, this spring three towns in Maine have gotten 
their communities to pass ordinances at town hall meetings that declare their food sovereignty and their perceived right to exempt local farmers and food producers who sell directly to the end user from state and federal food safety regulations (Quimby 2011). These ordinances seem to present yet another dimension to the arguments about scale and food safety, one that I think focuses on what the legitimate locus of regulatory decision making can and should be.

In closing, I want to summarize with this thought: Scale matters in the politics of food safety. And the time is ripe now for us to study these matters of scale.

\section{References}

Bottemiller, H. 2010. Coalition questions Tester's small-farm exemptions. Food Safety News, October 20. http://www.foodsafetynews. com/2010/10/consumer-public-health-groups-ask-for-testermodification/. Accessed 1 June 2010.

Delind, L.B., and P.H. Howard. 2008. Safe at any scale? Food scares, food regulation, and scaled alternatives. Agriculture and Human Values 25: 301-317.

Food and Drug Administration (FDA). 2010. Recall of shell eggs. http:// www.fda.gov/Safety/Recalls/MajorProductRecalls/ucm223522.htm. Updated 18 October 2010. Accessed 1 June 2011.

Food and Drug Administration (FDA). 2011. Background on the FDA Food Safety Modernization Act (FSMA). http://www.fda.gov/ Food/FoodSafety/FSMA/ucm239907.htm. Accessed 1 March 2011.

Grist. 2010. Food fight: The Food Safety Modernization Act. Grist Magazine, November 9. http://www.grist.org/article/food2010-11-05-food-safety-modernization-act. Accessed 1 May 2011
Martin, A. 2010. Egg recall exposes flaws in nation's food safety system. New York Times, August 24. http://www.nytimes.com/2010/08/25/ business/25eggs.html?ref=contamination_and_recall. Accessed 1 October 2010.

National Sustainable Agriculture Coalition (NSAC). 2010. Consumer groups issue badly flawed analysis of the pending Tester-Hagan food safety amendment. News release. http://sustainableagriculture. net/blog/consumer-groups-get-it-wrong-on-tester. Accessed 1 June 2011.

Nestle, M. 2010. Safe food: The politics of food safety. Berkeley, CA: University of California Press.

Quimby, B. 2011. A growing concern. Portland Press Herald, April 24. http://www.pressherald.com/news/growing_2011-04-24.html. Accessed 1 June 2011.

Western Growers Association (WGA). 2010. Western Growers opposes Food Safety Modernization Act S510. Statement from Western Growers' president and CEO Tom Nassif, November 19. http://www.wga.com/default.php?id=1034. Accessed 1 June 2011.

\section{Author Biography}

Neva Hassanein , PhD is a Professor in the Environmental Studies program at the University of Montana in Missoula, Montana. Her primary research interest is in social change with respect to environmental problems and sustainability. Much of her work focuses on the impacts of the conventional agriculture and food system and on local, sustainable alternatives to that system. She is also interested in the history and practice of the environmental movement, civic engagement, sustainable communities, ecological design, toxics, and feminist perspectives. She teaches courses in social qualitative research methods and participatory action research. 